\title{
Eksperimen Beton Mutu Tinggi Berbahan Fly Ash sebagai Pengganti Sebagian Semen
}

\author{
Fauna Adibroto, Etri Suhelmidawati, Azri Azhar Musaddiq Zade \\ Polytechnic State of Padang, West Sumatera \\ Email: etri.sarins@gmail.com
}

\begin{abstract}
Various research in concrete sector has been done as an effort to increase quality of concrete, materials and method, materials technology and implementation techniques obtained from the results of the experiments and experiments are intended to answer the increasing demands on the use of concrete and overcome the constraints that often occur in the implementation of work in the field. One way to increase the strength of concrete is to use a cement replacement that is fly ash.The purpose of this research is to know the influence of partial cement replacement effect with fly ash to the concrete compressive strength, in order to be applicated for rigid pavement in road design. The variations of composition in the addition of fly ash is $0 \%, 10 \%, 12.5 \%, 15 \%, 20 \%$ and $25 \%$ of the weight of cement. Concrete compressive strength is $40 \mathrm{MPa}$ and tested at 7 days and 28 days. This research tested concrete with cylinder test object (diameter $150 \mathrm{~mm}$ and height $300 \mathrm{~mm}$ ) with 30 sample and consist of 6 variation. From this research, optimum compressive strength at $10 \%$ variation is $30,770 \mathrm{MPa}$. The lowest compressive strength is in the $25 \%$ variation with $20,046 \mathrm{MPa}$. The highest compressive strength obtained from the research is $30.770 \mathrm{Mpa}$.
\end{abstract}

Keywords: Concrete, fly ash, compressive stength

\begin{abstract}
Abstrak-Berbagai penelitian dan percobaan dibidang beton dilakukan sebagai upaya untuk meningkatkan kualitas beton, teknologi bahan dan teknik-teknik pelaksanaan yang diperoleh dari hasil penelitian dan percobaan tersebut dimaksudkan untuk menjawab tuntutan yang semakin tinggi terhadap pemakaian beton serta mengatasi kendala-kendala yang sering terjadi pada pelaksanaan pekerjaan di lapangan. Salah satu cara untuk meningkatkan kekuatan beton adalah dengan menggunakan pengganti semen yaitu abu terbang. Tujuan dari penelitian ini adalah untuk mengetahui sejauh mana pengaruh penggantian sebagian semen dengan abu terbang terhadap mutu kuat tekan beton, sehingga bias digunakan untuk perencanaan perkerasan kaku pada jalan raya. Komposisi variasi penambahan abu terbang sebanyak $0 \%$, $10 \%, 12,5 \%, 15 \%, 20 \%$ dan 25\% dari berat semen. Mutu beton yang direncanakan $40 \mathrm{MPa}$ yang diuji pada umur 7 hari dan 28 hari. Penelitian ini menguji beton dengan benda uji selinder ( diameter $150 \mathrm{~mm}$ dan tinggi $300 \mathrm{~mm}$ ) sebanyak 30 sampel dan terdiri dari 6 variasi. Dari penelitian ini didapatkan kuat tekan optimum pada variasi $10 \%$ yaitu sebesar $30,770 \mathrm{MPa}$. Kuat tekan yang terendah terdapat pada variasi $25 \%$ yaitu sebesar 20,046 MPa. Kuat tekan tertinggi yang didapat dari penelitian yaitu 30,770 Mpa.
\end{abstract}

Kata kunci: Beton, fly ash, kuat tekan 


\section{PENDAHULUAN}

Pembangunan merupakan upaya yang dilakukan secara terus-menerus yang diarahkan pada peningkatan taraf hidup masyarakat dan kesejahteraan secara umum. Dalam pelaksanaannya, perkembangan ilmu pengetahuan dan teknologi memacu adanya pengembangan kreatifitas setiap orang sebagai modal agar pembangunan dapat dilaksanakan secara labih baik. Seiring dengan hal tersebut, peningkatan mutu, efisiensi, dan produktivitas dari setiap kegiatan pembangunan terutama yang terkait dengan sektor fisik mutlak harus dilakukan, seperti halnya sektor bangunan yang saat ini terus mengalami peningkatan.

Dalam dunia konstruksi bangunan, penelitian untuk mendapatkan produk konstruksi yang lebih baik terus dilakukan. Beton yang merupakan salah satu material penting dari sebuah bangunan. Pada dasarnya beton terbentuk dari dua bagian utama yaitu pasta semen dan agregat. Pasta semen terdiri dari semen Portland, air dan bahan campur tambahan (admixture). Sedangkan agregat terdiri dari agregat kasar (batu pecah) dan agregat halus (pasir). Beton banyak digunakan karena keunggulan-keunggulannya antara lain kuat tekan beton mutu tinggi.

Beton merupakan material yang kuat dalam kondisi tekan dan lemah dalam kondisi tarik, merupakan elemen struktur yang paling banyak digunakan dalam bangunan karena bahannya yang mudah didapat, mudah dibuat dan harganya murah.Kualitas beton tergantung pada bahan-bahan penyusunnya, namun untuk membuat beton mutu tinggi yang sesuai dengan yang diinginkan tidak serta merta diperoleh dengan hanya mencampurkan semen portland atau jenis semen yang lain, agregat kasar, agregat halus, dan air.

Peningkatan kualitas campuran beton akan menghasilkan beton mutu tinggi. Pemakaian beton mutu tinggi dan berkinerja tinggi merupakan material bangunan yang sudah banyak digunakan dalam pelaksanaan struktur bangunan bertingkat tinggi. Kualitas yang baik pada campuran beton dengan bahan tambah (admixture), bertujuan untuk mengubah satu atau lebih sifat-sifat bahan penyusun beton yang baik dalam keadaan segar maupun setelah keras, seperti bahan tambah abu terbang (fly ash).

Abu terbang atau fly ash adalah produk sampingan dari industri Pembangkit Listrik Tenaga Uap (PLTU) yang menggunakan batubara sebagai bahan bakar, berupa butiran halus ringan, bundar, tidak porous serta bersifat pozzolanik. Penambahan abu terbang (fly ash) pada campuran beton bersifat pozzolan, sehingga bisa menjadi additive mineral yang baik untuk beton. Pozzolan adalah bahan yang mengandung silika atau silika dan alumunium yang bereaksi secara kimia dengan kalsium hidroksida pada temperatur biasa membentuk senyawa bersifat cementitious.

Penelitian ini mencoba memanfaatkan kondisi alam Indonesia maupun pemanfaatan bahan-bahan lokal yang memungkinkan dilaksanakannya pembuatan beton bermutu tinggi. Usaha penelitian perlu dilakukan untuk mendapatkan suatu alternatif baru dalam teknologi beton, dengan menggunakan semen yang seefisien mungkin yaitu dengan 
menggantikan sebagian semen dengan abu terbang (fly ash) sehingga pemakaian abu terbang (fly ash) diharapkan dapat menghasilkan kuat tekan beton yang lebih tinggi.

\section{KAJIAN TEORI}

Beton adalah campuran antara semen portland atau semen hidraulik yang lain, agregat halus, agregat kasar dan air, dengan atau tanpa bahan tambahan yang membentuk masa padat (SNI-03-2847-2002). Beton mutu tinggi adalah beton dengan perlakuan khusus dan persyaratan yang seragam yang tidak dapat selalu dicapai secara rutin hanya dengan penggunaan material konvensional dan pencampuran secara normal, penempatan dan cara perawatannya (American Concrete InstituteNo.211.4R-93).

Sesuai dengan perkembangan teknologi beton yang demikian pesat, ternyata kriteria beton mutu tinggi juga selalu berubah sesuai dengan kemajuan tingkat mutu yang berhasil dicapai. Pada tahun 1950an, beton dengan kuat tekan $30 \mathrm{MPa}$ sudah dikategorikan sebagai beton mutu tinggi. Pada tahun 1960an hingga awal 1970an, kriterianya lebih lazim menjadi $40 \mathrm{MPa}$. Saat ini, disebut mutu tinggi untuk kuat tekan diatas $50 \mathrm{MPa}$, dan $80 \mathrm{MPa}$ sebagai beton mutu sangat tinggi, sedangkan $120 \mathrm{MPa}$ bisa dikategorikan sebagai beton bermutu ultra tinggi (Budi2008, Ervianto 2016, Gunaedi 2013, Lincolen 2017, Mardiono 2010, Suhelmidawati 2003, Umbroh 2014).

\section{METODA PENELITIAN}

Penelitian Beton Mutu Tinggi (High Strength Concrete) ini dilakukan di Laboratorium Bahan Jurusan Teknik Sipil
Politeknik Negeri Padang, yang meliputi pengujian pendahuluan dan pengujian lanjutan.Dalam penelitian ini digunakan bahan material berupa semen Portland tipe I, air, agregat kasar (kerikil), halus (pasir) dan abu terbang (fly ash) tipe $\mathrm{F}$.

Rincian bahan campuran beton pada penelitian ini adalah sebagai berikut :

1. Semen Portland tipe I merek PT. Semen Padang

2. Agregat kasar berasal dari Laboratorium Bahan Jurusan Teknik Sipil Politeknik Negeri Padang

3. Agregat halus berasal dari Laboratorium Bahan Jurusan Teknik Sipil Politeknik Negeri Padang

4. Air diambil dari Laboratorium Bahan Jurusan Teknik Sipil Politeknik Negeri Padang

5. Abu terbang (fly ash) tipe $\mathrm{F}$ berasal dari PLTU Sijantang Kota Sawahlunto

Jumlah sampel dan kadar Fly Ash yang terdapat didalamnya bisa dilihat pada tabel berikut:

Tabel 3.1 Jumlah Benda Uji

\begin{tabular}{|c|c|c|c|}
\hline \multirow{3}{*}{$\begin{array}{c}\text { Jenis } \\
\text { Benda Uji }\end{array}$} & \multirow{2}{*}{$\begin{array}{c}\text { Kadar Fly } \\
\text { Ash }\end{array}$} & \multicolumn{2}{|c|}{ Jumlah Benda Uji } \\
\hline & & \multicolumn{2}{|c|}{ Umur Rencana } \\
\hline & $(\%)$ & 7 hari & 28 hari \\
\hline BN & 0 & 3 & 3 \\
\hline BMT 1 & 10 & 3 & 3 \\
\hline BMT 2 & 12,5 & 3 & 3 \\
\hline BMT 3 & 15 & 3 & 3 \\
\hline BMT 4 & 20 & 3 & 3 \\
\hline BMT 5 & 25 & 3 & 3 \\
\hline \multirow{2}{*}{\multicolumn{2}{|c|}{ Total Benda Uji }} & 18 & 12 \\
\hline & & \multicolumn{2}{|c|}{30} \\
\hline
\end{tabular}

Pengujian pendahuluan dimaksudkan untuk menguji karakterisitik dari material dasar yang digunakan dalam pembuatan beton, apakah 
memenuhi persyaratan atau tidak. Kemudian data-data tersebut digunakan dalam perhitungan rencana campuran beton (mix design).

Perencanaan campuran (mix design) sesuai dengan standar ACI 211.4R-93 dengan variasi penggantian semen dengan bahan pozzolan (fly ash) yang digunakan adalah sebesar $10 \%, 12,5 \%, 15 \%, 20 \%$, dan $25 \%$ dari total volume semen.

Dalam penelitian ini dilakukan pengujian pada beton segar (fresh concrete) yaitu pengujian Slump Test. Selain pengujian pada beton segar juga dilakukan pengujian pada beton keras (hardened concrete) yaitu pengujian kuat tekan beton dengan sampel 15 x 30 cm pada umur 7 dan 28 hari.

\section{ANALISA HASIL UJI LABORATORIUM}

Pengujian kuat tekan beton ini dilakukan dengan mesin uji tekan sampai kondisi beton uji rusak. Untuk memperjelas penyajian hasil penelitian, berikut ini akan diuraikan ringkasan hasil pengujian.

Tabel 4.1 Nilai Slump Pada Tiap Variasi

\begin{tabular}{|c|c|c|c|c|}
\hline \multirow{2}{*}{ No } & \multirow{2}{*}{$\begin{array}{c}\text { Jenis } \\
\text { Benda Uji }\end{array}$} & $\begin{array}{c}\text { Kadar } \\
\text { Fly Ash }\end{array}$ & \multicolumn{2}{|c|}{$\begin{array}{c}\text { Nilai slump rata- } \\
\text { rata }\end{array}$} \\
\cline { 4 - 5 } & & 7 hari & 28 hari \\
\hline 1 & BN & 0 & 6,30 & 6,25 \\
\hline 2 & BMT 1 & 10 & 6,75 & - \\
\hline 3 & BMT 2 & 12,5 & 7,00 & - \\
\hline 4 & BMT 3 & 15 & 5,33 & 5,50 \\
\hline 5 & BMT 4 & 20 & 5,83 & 5,33 \\
\hline 6 & BMT 5 & 25 & 7,33 & 6,00 \\
\hline
\end{tabular}

Hasil penelitian yang berupa data-data kasar, selanjutnya dianalisis untuk mengetahui pengaruh bahan pengganti sebagian semen dengan menggunakan fly ash yang berasal dari PLTU Sijantang Kota Sawahlunto terhadap kuat tekan beton. Pada Tabel 4.1, terlihat nilai slump yang diperoleh masuk

Tabel 4.2 Rekapitulasi Hasil Penelitian

\begin{tabular}{|c|c|c|c|c|c|}
\hline \multirow{2}{*}{\multicolumn{2}{|c|}{$\begin{array}{c}\text { Jenis Benda } \\
\text { Uji }\end{array}$}} & \multirow{2}{*}{$\begin{array}{c}\text { Kadar } \\
\text { Fly } \\
\text { Ash } \\
(\%)\end{array}$} & \multicolumn{2}{|c|}{$\begin{array}{c}\text { Umur Benda Uji } \\
\text { (MPa) }\end{array}$} & \multirow{2}{*}{$\begin{array}{c}\text { Kuat } \\
\text { Tekan } \\
\text { rata-rata } \\
\text { pada } 28 \\
\text { hari } \\
\text { (MPa) }\end{array}$} \\
\hline & & & 7 Hari & 28 Hari & \\
\hline \multirow{3}{*}{$\mathrm{BN}$} & (1) & \multirow{3}{*}{0} & 21,745 & 29,426 & \multirow{3}{*}{28,134} \\
\hline & (2) & & 22,133 & 25,258 & \\
\hline & (3) & & 29,385 & 29,718 & \\
\hline \multirow{3}{*}{$\begin{array}{c}\text { BMT } \\
1\end{array}$} & (1) & \multirow{3}{*}{10} & 21,324 & 32,810 & \multirow{3}{*}{30,770} \\
\hline & (2) & & 21,981 & 33,820 & \\
\hline & (3) & & 16,683 & 25,690 & \\
\hline \multirow{3}{*}{$\begin{array}{c}\text { BMT } \\
2\end{array}$} & (1) & \multirow{3}{*}{12,5} & 13,351 & 20,540 & \multirow{3}{*}{28,040} \\
\hline & (2) & & 19,972 & 30,730 & \\
\hline & (3) & & 21,355 & 32,850 & \\
\hline \multirow{3}{*}{$\begin{array}{c}\text { BMT } \\
3\end{array}$} & (1) & \multirow{3}{*}{15} & 18,408 & 25,263 & \multirow{3}{*}{25,839} \\
\hline & (2) & & 16,712 & 26,657 & \\
\hline & (3) & & 16,930 & 25,596 & \\
\hline \multirow{3}{*}{$\begin{array}{c}\text { BMT } \\
4\end{array}$} & (1) & \multirow{3}{*}{20} & 15,157 & 23,951 & \multirow{3}{*}{24,601} \\
\hline & (2) & & 15,447 & 24,529 & \\
\hline & (3) & & $16 . .204$ & 23,658 & \\
\hline \multirow{3}{*}{$\begin{array}{c}\text { BMT } \\
5\end{array}$} & (1) & \multirow{3}{*}{25} & 14,291 & 18,716 & \multirow{3}{*}{20,046} \\
\hline & (2) & & 15,912 & 21,241 & \\
\hline & (3) & & 14,923 & 21,847 & \\
\hline
\end{tabular}

Berdasarkan hasil pengujian kuat tekan yang telah dilakukansebagaimana di Tabel 4.2 danGambar 4.1, nilai kuat tekan rata-rata tertinggi didapat pada sampel BMT 1 yaitu beton yang menggunakan variasi fly ash sebesar $10 \%$ dengan kuat tekan rata-rata $30,770 \mathrm{MPa}$, dan kuat tekan rata-rata terendah didapat pada sampel BMT 5 yaitu beton yang menggunakan variasi fly ash sebesar $25 \%$ dengan kuat tekan rata-rata 20,046 MPa. Berdasarkan data hasil penelitian diatas, dapat diambil kesimpulan bahwa nilai kuat tekan 
beton mengalami peningkatan sampai umur 28 hari dengan kuat tekan tertinggi $30,770 \mathrm{MPa}$ pada variasi fly ash $10 \%$ kemudian diikuti oleh variasi fly ash $12,5 \%$. $15 \%$, $20 \%$, dan $25 \%$.

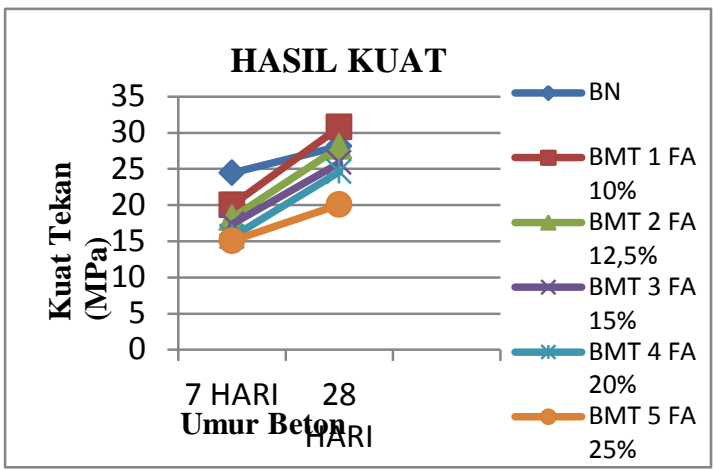

Gambar 4.1. Grafik Hasil Nilai Kuat Tekan

Dari grafik 4.1 diatas, dapat dilihat bahwa kuat tekan pada sampel beton tanpa fly ash (BN) memiliki nilai kuat tekan yang tinggi di awal sedangkan beton yang menggunakan fly ash memiliki nilai kuat tekan dibawahnya. Ini membuktikan bahwa sifat dari campuran bahan fly ash pada beton yaitu memiliki nilai ikat awal yang rendah. Namun seiring berjalannya waktu kuat tekan beton normal mengalami perlambatan, sebaliknya beton dengan campuran bahan fly ash mengalami peningkatan kuat tekan yang cukup tinggi karena aktifitas dari pozzolannya yang terus berlanjut.

\section{KESIMPULAN DAN SARAN}

Berdasarkan data hasil penelitian diatas dan hasil penelitian-penelitian yang sudah dilakukan, dapat diambil kesimpulan bahwa nilai kuat tekan beton dapat mengalami peningkatan sampai umur 28 hari dengan kuat tekan tertinggi $30,770 \mathrm{MPa}$ pada variasi $10 \%$ kemudian diikuti variasi $12,5 \%, 15 \%, 20 \%$,
$25 \%$. Kuat tekan tertinggi 30,770 MPa dengan variasi Fly Ash $10 \%$, melebihi kuat tekan beton normal pada umur 28 hari yaitu $28,134 \mathrm{MPa}$. Sehingga berdasarkan hasil uji kuat tekan ini, penggunaan variasi Fly Ash $10 \%$ bias digunakan untuk perencanaan perkerasan jalan kaku, sebagaimana tujuan dari penelitian ini.

Ada beberapa saran yang bisa diambil yaitu dalam pembuatan High Strength Concrete diperlukan campuran material yang berkualitas. Ketelitian dalam perencanaan ( $m i x$ design), sumber material, jenis, serta dalam penimbangan material sangat menentukan kualitas dan kekuatan beton. Selain itu perlu adanya penelitian mengenai proses perawatan beton mutu tinggi (High Strength Concrete) dengan cara dibakar atau dipanaskan dalam oven, mengingat abu terbang (fly ash) memiliki ketahanan terhadap suhu yang ekstrim. Untuk umur perawatan beton, diperlukan pengujian hingga 56 hari perendaman mengingat proses pengikatan abu terbang (fly ash) ini tidak sama dengan semen yang hanya memerlukan 28 hari umur perawatan. Perlu adanya zat aditif tambahan seperti Bestmittel, Expanded Polystyrene, Super plasticizer Sika Viscocrete dan bahan tambahan lainnya seperti abu sekam padi atau serat kaca untuk menunjang dan meningkatkan nilai kuat tekan beton.

\section{DAFTAR PUSTAKA}

American Concrete Institute (ACI) No.211.4R93, Guide for Selecting Proportions for High Strength Concrete With Portland Cement and Fly Ash, ACl Committee 211.

Budi, Aswin,Kuat Tekan dan Kuat Tarik Beton Mutu Tinggi dengan Fly Ash sebagai Bahan Pengganti sebagian Semen 
dengan f'c $45 \mathrm{MPa}$. Yogyakarta : Universitas Islam Indonesia, 2008

Departemen Pekerjaan Umum, Tata Cara Pembuatan Rencana Campuran Beton Normal, SNI 03-2834-1993, Departemen Pemukiman dan Prasarana Wilayah, Badan Penelitian Dan Pengembangan, Jakarta, 2002

Ervianto, Mochammad, Fadillaway dan Hakas Prayuda, Kuat Tekan Beton Mutu Tinggi menggunakan Bahan Tambah Abu Terbang (Fly Ash) dan zat aditif (Bestmittel). Yogyakarta : Universitas Muhammadiyah Yogyakarta, 2016

Gunaedi dan Rahmat Hidayat,Pengaruh Fly Ash pada Kuat Tekan Campuran Beton menggunakan Expanded Polystyrene sebagai Substitusi Parsial Pasir. Jakarta : Universitas Binus, 2013

Lincolen, Kevin, Pengaruh Abu Terbang sebagai Bahan Pengganti Semen pada Beton Beragregat Halus Bottom Ash. Bandar Lampung : Universitas Lampung, 2017

Mardiono, Pengaruh Pemanfaatan Abu Terbang (Fly Ash) dalam Beton Mutu Tinggi. Jakarta : Universitas Gunadharma Jakarta, 2010

R. E. Davis, R. W. Carlson, J. W. Kelly dan H. E. Davis, Properties of Cements and Concretes containing Fly Ashes. American Concrete Institute Journal, 33 : pp. 577-612, 1937

SuhelmidawatiEtri, Penelitian Beton Mutu Sangat Tinggi (Ultra High Strength Concrete). Padang : Universitas Andalas, 2003

Standar Nasional Indonesia (SNI) No. 036468-2000 Pd T-18-1999-03, Tata Cara Perencanaan Campuran Beton Berkekuatan Tinggi Dengan Semen Portland dan Abu Terbang, Badan Standardisasi Nasional, Jakarta, 2010.

Umbroh, Alfian Hendri, Pengaruh Pemanfaatan Abu Terbang (Fly Ash) dari PLTU II Sulawesi Utara sebagai Substitusi Parsial Semen terhadap Kuat Tekan Beton. Manado : Universitas Sam Ratulangi, 2014 